\title{
Udo Etuk on the "God of Africa”: A Response
}

\author{
Francis Etim \\ Department of Philosophy University of Uyo, Uyo, Nigeria \\ Email: etimfrank@yahoo.com
}

How to cite this paper: Etim, F. (2018). Udo Etuk on the "God of Africa": A Response. Open Journal of Philosophy, 8, 565-577.

https://doi.org/10.4236/ojpp.2018.85041

Received: October 27, 2018

Accepted: November 27, 2018

Published: November 30, 2018

Copyright $\odot 2018$ by author and Scientific Research Publishing Inc. This work is licensed under the Creative Commons Attribution International License (CC BY 4.0).

http://creativecommons.org/licenses/by/4.0/

\section{(c) (i) Open Access}

\begin{abstract}
Some scholars like Rabbi Ini Mbebeng, Rabbi Ettah Essien and Prof Udo Etuk have argued against Ibibio nay Africans having the idea of Supreme Being identical with that of the West given their polytheistic conception of God with attendant pan-theistic proclivities. On the other hand, scholars like Idowu regard such position as anachronistic and retrogressive since African has what he calls, "diffused monotheistic" idea of God which in description and analysis is similar to that of Western typology. This article as a contribution to that debate examines Abasi as a name of the God among the Ibibio from philo-ontos-linguistic perspectives and comes to the conclusion that not only is it true that the Ibibio nay Africans in general have a superlative idea of God but that the African idea of God is more humanistic and existentially relevant than that of the West thus solving the attendant difficulties of explaining the relationship between God and the world and the issue of the problem of evil which resulted in such idea as Dues abscunditus in Western conception of God.
\end{abstract}

\section{Keywords}

God, Africa, God of Africa, Udo Etuk, Incultration, Diffused Monotheism

\section{Introduction}

Africans are considered to be "notoriously" religious; their entire life is believed to be suffused and directed by their religious proclivities. It becomes then disturbing for anyone to question this basic assumption about Africa to the point of denying Africans a valid conception of God that could be justified as worthy of commitment and faith. This, indeed, is Professor Udo Etuk's submission in an article titled "The God of Africa" in his book, Religion and Cultural Identity (2002).

In his usual desire to establish "the Relevance of Philosophy and Philosophy of Relevance" and following his advocacy in Riches of Philosophy (Udo Etuk, 
2000) for bringing Philosophy to bear on issues of our local concerns instead of re-inventing Aristotle and Plato in apparent over flocked manner, he painstakingly discusses the issue of God as it pertains to Africa. He saw the belief in God as an area of conflict between Christianity and traditionalism in Africa. With the wealth of philosophy, religion and theology as his background and oscillating between Philosophy of Religion, Sociology of Religion and Theology, Udo Etuk sees this conflict as inevitable given the fact that "Christianity is still regarded as an alien or imported religion, while traditionalism still retains its grip on the people" (Udo Etuk, 2002). As would be expected, this has most often resulted in challenging and confronting scenarios between Christian values and beliefs and traditional beliefs, values, convictions and cultural practices. Ordinarily, one would have thought these conflicts to have fizzled out with many decades of African embrace of Christianity especially among the Ibibio which he chose as his locale of consideration. However, based on his pastoral experience, Udo Etuk sees this conflict to be persistent, prevalent and tenacious resulting in superficial profession of faith and ambivalent life style of Christians especially in challenging situations. Udo Etuk corroborates his position by painting a typical scenario thus:

When any of the crises of life scratches us a little, such as serious health problems, disasters and misfortune including death, especially if these appear to be inexplicable, then one is likely to encounter beneath the surface a solid core of traditional beliefs and practices which cannot be reconciled at all with Christian teachings and standards (2002).

E. Bolaji Idowu attributed this syncretism among the Africans to "the problem of divided loyalties, of unresolved ambivalence, of a token worship and skin-deep devotion to the God of Christian religion but total immersion in the traditional practices of our people" (1973).

What could have led to this unfortunate scenario is not far-fetched given the alien nature of Christianity that almost shredded the fabric of African belief system apart such that Chinua Achebe (1958) in Things Fall Apart could exclaim through the mouth of Okonkwo that they have put a knife in the things that held us together and we have fallen apart. Even some Africans, whether literate or learned, believe that most calamities that have befallen Africa can be attributed to “'abandoning the God of Africa' by not giving to Caesar what belongs to Caesar and to God what belongs to God" (2002).

With a curiosity that usually characterized and ignited philosophical reflection, Udo Etuk then drawing from the above scenarios sought to find out whether there is a "God of Africa" identical with, different from or related to the God of Western Christianity. While some would be inclined to think that both are the same; others, like Udo Etuk's lawyer-friend insinuations points to the fact that "the two could not be identical" (2002) Udo Etuk is however, fast to point out that some scholars like Idowu considers such notion of "the God of Africa" as a "political invention" created to distinguish it from the ratiocentric 
"God of the West". If Idowu's reasoning is correct without strains in the heart and lives of the masses, then Udo Etuk reasons that there would be no problem of "divided loyalties" as contended by Idowu. This then provided Udo Etuk the impetus needed to examine the issue.

The issue and discussion is contextualized in Ibibio ethnic group of south-east Nigeria not only for the fact that that is Udo Etuk's native land but where he spent most of his pastoral life. Others but very important reasons he adduced for the delimitation in scope include inter alia the fact that they are predominantly Christian in today's reckoning with "a good century-and-a-half Christian history", the first language in all Africa to have received a complete translation of the Christian scriptures, which invariably implies their early familiarity with the basic Christian doctrine coupled with the fact that they had the privilege of hosting renowned missionaries like Mary Mitchell Slessor and Samuel Alexander Bill (Udo Etuk, 2002). The prevalence and persistence of conflicts between the traditional beliefs and Christianity and syncretism among Ibibio Christian in spite of these substantial pedigree makes Udo Etuk to ask whether "Christianity with its Western categories are something foreign to and at odds with the indigenous religion and its beliefs system: or, whether the God of African (Ibibio) Traditional Religion though monotheistic as suggested by Idowu, is identical with the Supreme God of Christian religion?” (2002).

\section{Udo Etuk: His Background}

A better understanding of Udo Etuk's background would make one appreciates his worries, concern and submissions. Udo Etuk is a seasoned academic, a professor of philosophy with an eclectic mind who believes in a holistic study of philosophy without the fragmentary emphasis of the contemporary period with over indulgence on specialization. He believes, above all, in the relevance of philosophy especially to our continent, Africa that is ridden with so many issues begging for philosophical attention. Such application of philosophy (philosophy of relevance) to issues of local concern will go a long way not only in salvaging our society but establishing the worth of philosophy in a scientifically suffused world.

Besides being a philosopher, Udo Etuk is prima facie a Minister of the Gospel in the Lutheran Church of Nigeria, an avid broadcaster and a radio preacher where he marries his wealth of philosophy with theology for a Christian apologetic and evangelization; a prolific writer with enviable and commendable articles in local and international Journals, a score of workshop papers and many conference papers on both religious, social and political issues. A fine bred gentleman; probably ensuring from the fact that he is well tutored and learned; a blend of philosophy and theology_rationality and faith.

It is within this back drop that one can understand his apprehension about the "God question" in Africa since he is writing an apologetic in defense of Christian faith. This could be gleaned from his comments that his aim and little effort in this book might have been sub-titled or summarized as "earnestly contending 
for the faith" as contained in Philippians 1: 27. Many would wonder why he has to undertake this kind of hair splitting exercise which appears to be a futile polemics, a waste of time, useless and unnecessary in the face of the fact that the ordinary African (Ibibio) Christian or believer goes to church to worship Abasi Ibom and to pray to Abasi Ibom with faith in His existence as his/her creator and sustainer. The analysis and examination of the name of God does not then add or diminished his/her faith in God.

But as I observed in Issues in Philosophy of Religion (Etim, 2006) that since no human phenomenon can escape philosophical scrutiny, religion with all its complexity of nature, diversity of manifestations and expressions and tenacity of control on man is sure to attract the philosopher's attention. Otherwise how else can we distinguish between the true and the false, the perfect and the imperfect act; or escape easy acceptance of what may prove to be intrinsically unworthy of commitment.

Indeed, no doubt commitment is intrinsic to religion for vitality; nevertheless, the precise object of the commitment is all important. That is why philosophy is required when man recognizes competing or mutually incompatible faiths and begins to ask; "which faith?" (Etim, 2006). Otherwise, "anything that is worshiped can be termed a god, inasmuch as the worshiper attributes to it Might greater than his own and venerates it" (Mbebeng, N.Y). This is actually what Udo Etuk, the philosopher cum theologian is asking by theologizing on the God question in Africa. Such understanding will go a long way to inform belief, enrich worship, deepen faith, and erase syncretism and ambivalence in Christian practices among the Ibibio.

\section{God of Africa: Udo Etuk's Argument}

Do the Africans have a concept of the Supreme Being? Which God for Africa? Is "the God of Africa" a political invention? Is the Supreme Being recognized in all acts of indigenous worship identical with Jehovah of Jewish conception? Is the African God concept the same as that of the Europeans? These are the questions among others that Udo Etuk asked.

To answer these array of questions and typical of Udo Etuk of not accepting sweeping statements, he took pains to examine the submissions of various authors especially theologians of African origin like Prof. E Idowu of Nigeria and Prof. John Mbiti of Kenya who, however, as noted by Udo Etuk, may not be specialists in African Theology. The duo actually maintains vehemently that God is real in Africa. For Mbiti (1970), all the ethnic groups in Africa have some idea of the Supreme Being, the Most High God of heaven ascribed with superlative attributes like omnipotence, omniscience, immanence and transcendence, self-existence, eternity and incomprehensibility (Udo Etuk, 2002). Idowu too thinks in the same light maintaining that God is real to Africans in that each people has a local name for God with a qualifying prefix to distinguished it from other divinities (Idowu, 1973). To Udo Etuk's mind, both Idowu and Mbiti's submissions should be appreciated within the backdrop of the time of their 
writing as apologia virtually "begging" for recognition from the world that Africans have idea of God and in response to detractors who denied Africans capacities for such lofty a concept. While wondering why Africans have to undertake such stressful endeavour in virtually all field of human endeavour, Udo Etuk, however, sees it as not too useless a venture since one can discover one's strength through such an exercise. On the whole, Udo Etuk acknowledges the fact that nearly all scholars who have undertaken to study the African religious consciousness have reached one conclusion that the idea of God or rather of the Supreme Being is not foreign to Africa. In fact, as argued by Parrinder (1976) "African people had a belief in a Supreme Being as an integral part of their worldview and practiced religion". Same idea is embedded in R.S. Rattray's submission as quoted by Mbiti that “...it is true that the great Supreme Being, the conception of whom has been innate in the minds of Ashanti, the Jehovah of the Isrealites" (Idowu, 1973).

Deducing from the above submissions, and juxtaposing African beliefs in the Supreme Being with that of the ancient religions of the world, with their varied but glowing and superlative concepts of the Supreme Being like Dinah of Ephesus, Demetrius of Asia, the Roman Jupiter, the Greek Zeus and the Canaanite's Baal which have been supplanted with time with the Jehovah God, Udo Etuk (2002). Then submits that:

... the fact that a people have the concept of a Supreme Being who has all the wonderful and majestic epithets does not necessarily make that "Supreme Being" identical with Jehovah. This applies whether the people in question are Africans or Asians or Near Easterners

Arguing further Udo Etuk (2002) asks if African traditional religion is monotheistic as Idowu suggests and monotheism is defined as the belief in one God, then we need an explanation of the nature, the role and duties of the deities or divinities which populate this theocracy. Above all, we need to be told their relationship to the Supreme Being. Because in the final analysis, what matter is not what name is given to a religion, but the attitude of the devotee to the object of worship

From the analysis and examination of the word "Believe in", "the nature and reality of the divinities" and "the relationship of the divinities to the Supreme God", Udo Etuk (2002) concludes rhetorically by asking, "if our religion is monotheistic then why do its claims conflict with the central claims and creed of the Christian religion and why the problem of "divided loyalties": If the divinities are emissaries of the Supreme God, why do they accept sacrifice that is repudiated by the Christian God?"

Udo Etuk is not alone as Rabbi Ini Mbebeng and Rabbi Ettah B. Essien in a pamphlet titled, "Christianity in Efik and Ibibio Nations: So Far So Bad" in apparent corroboration of Udo Etuk's position opine:

The strange and unimaginable question is whether the names Nigerians use 
in worship on Sundays and Saturdays in churches and synagogues are devoid of ancient idolatrous worship similar to the ones mentioned in the Bible which came from Babylon. The Igbos knew Chi and Chukwu before the Bible came to Nigeria. Yorubas knew Oluwa, Olorun and other gods before the Bible came. All societies outside Israel had known one deity or another before the knowledge of the Bible got to them (NY).

Their response in the case of Ibibio Abasi Ibom is a vehement No based on some reasons which they adduced as follows:

1) Abasi Ibom never spoke to any Efik, Ibibio, or Annang worshiper to tell him that that is his name is to be honoured forever

2) It was a mix-up and lack of knowledge or wisdom that the translators of the English Bible into Efik language unknowingly transferred the ancient name of Ibom deity into the Efik Bible.

3) Like the deities of the Greeks, the Efik and Ibibio/Annang deities can sometimes quarrel among themselves, fought against one another

4) Abasi Ibom is not different from other gods of nations in that the title "Oku Ibom" meaning "Ibom Priest" is exclusively reserved for traditional rulers. This means "Ibom" was and still is a deity of the nations of Efik, Ibibio and Annang as ancient traditional societies. If Ibom or Abasi Ibom were any title near the creator in the Bible, the church generals could have been the ones named Oku Ibom (Ibom Priest) (N.Y).

Regarding the validity and reasonableness of Ibibio theocracy, Udo Etuk (2002) argues further that if the divinities are emissaries of the Supreme God and they demand and accept sacrifices, then that Supreme God cannot be the same as the God of Christian religion because this God in His revealed will to man makes very absolute claims about who should be worshipped and the kinds of sacrifices that His people need to render today.

For Rabbi Mbebeng and Essien (N.Y.), the Ibibio Abasi Ibom could best be described as one of the gods acknowledged in the Christian Scriptures (C.F. The Holy Bible, 1971: Ps. 86: 8; 1 Cor.8: 5, 6) that are seen as valueless. The duo further identifies the Western "God" as of similar characteristics and nature considering its original usage and application. For them, most revealing is the shocking fact to every reasonable English Bible reader that "God" was originally the name of a deity in a Teutonic tribe in Europe and after years of usage was adopted into English as a common noun for anything humans (SIC) worship (N.Y.).

Deductively, Mbebeng and Essien (N.Y). then submit that it is left for the Bible believer to decide whether it is correct to use the word "God" when referring to the Creator of all things instead of the Hebrew word "El", "Elohim", "Eloah"... e.g. Yahweh Elohim and not "Yahweh God" or "My Elohim" and not "My God" So, to be God, in the truest sense of the word it must be in Hebrew rendition; no more no less. Udo Etuk, however, apparently accept the English rendition may be because he was not concerned with the name but with the essence of the God in question. 


\section{My Response: In Defense of "The God of Africa"}

Anyone who is familiar with African metaphysics knows that there is something in a name (This paper does not intend to go into the polemics of the existence and non-existence of African metaphysics). The Ibibio like other Africans and the Jews are not nominalists (those who believe that names are flatus voce, mere words without meaning or imports) but believe that names are pregnant with meanings; it is even a pointer to the essence of a thing. This is evident during child-naming ceremonies with all the attendant religious and ritualistic performances. So the Ibibio name for the Supreme Being is not empty and whimsical The Supreme Being known with varied renditions such as Abasi Ibom, Aba-nsi-nsi, Abasi Asana Enyong, Abasi Enyong, Ndu Ndu Abasi, connote various attributes like supreme, omnipotence, omniscience, transcendent, powerful, ubiquitous, everlasting, among others.

In Metaphysics of African Medicine (Etim, 2013b) and African Philosophy: The Story So Far (Etim, 2013a), I acknowledge the fact that the Ibibio theocracy actually recognizes the existence of one Supreme deity called Abasi Enyong or Abasi Ibom. In African Philosophy. The Story So Far (Etim, 2013a), again, I argued to the fact that the very derivation of the name Abasi Ibom or Abasi Enyong depicts a being whose being is ontologically transcending, subsisting and substantial. Both Abasi Ibom and Abasi Enyong are compound words-Abasi and Ibom and Abasi and Enyong. The word Abasi itself is a word taken from a building terminology-Abai that refers to the king post of a house upon which the entire house rests. The abai is usually hewn from trees like Cedar, Iroko, and Timber which the Ibibio believe to have the capacity for longevity through the seasons and years and sometimes even outlive the life span of a particular building. By inference, $A b a-s i$ is believed to be the king post of all that exist and can live forever (nsi nsi) like the abai. Hence, the name Aba (si). The $s i$ is a contraction of the word nsi nsi. Ibom and enyong, the other component of the name, refers to a very distant town and the sky, respectively. Ibom actually depicts the pinnacle, the apex and the first settlement of the Ibibio before their migration to the present location. So, Abasi Ibom, is by nature eternal, transcendental and pure spirit, therefore, distant from the people. This idea of distance and sky is implicit and explicit in the designation of God in Ibibio as Abasi asana enyong (The God of the clear sky). The distant sky is taken to be His abode, so He is apparently distant from the abode of men. It is this transcendental nature as pure spirit without any shrine as abode that makes the Ibibio approach Him through intermediaries like the ancestors and localized deities (Ndem) using sacrifices and rituals. Ibibio theocracy is, however, hierarchically structured with Abasi Ibom at the apex and other beings like Abasi isong (the earth god or localized deities), the ancestors, man, plant and animals as part and parcel of the structure with peculiarity of nature and functions (cf. also Udo, 1983; Esen, 1982).

The localized deities as the name implies are not transcendental but localized in trees, rivers, streams, mountains, etc, therefore part and parcel of the physical 
universe though at the spiritual level. The Ibibio are not very clear about their nature. As gods, they are believed to be spiritual in nature but localized in space and time. There is virtually a deity for anything of existential importance to the Ibibio like thunder, war, fertility in women, agriculture and fishing among others. Men approach them in times of unexpected happenings in their area of jurisdiction. It is, however, not clear whether Abasi Ibom creates these gods but, like the Abasi Ibom they are immortal. The localized deities could then be analogous to angels in Christian conception who, though immortal, are still creations of the Supreme God. Like the angels too, they are known by their functions within the community. Their importance is determined by the role they play in the existential dynamism of the community. Hence, not all deities are given equal regard and reverence. Some of them, their area of influence are limited to the family and village, while others are extended to the larger community called clan. The larger their area of influence, the more popular and respectful the deity is regarded.

The problem here is that both are called Abasi with the distinction made only with the component part isong which means terrestrial, earth, the physical universe and so on. And the Ibibio also offer sacrifices to them sometimes as if they are "ends in themselves" and sometimes as intermediaries of the Abasi Ibom. There are moments and occasions that the Ibibio explicitly express faith in the Abasi Ibom over belief in other deities. However, for a superficial observer Abasi isong would appear to be in-charge of the terrestrial plane while Abasi Ibom governs the sky. Given this misconception, then Udo Etuk's refusal to accord Ibibio theocracy a monotheistic status would be right. And his conclusion that the Ibibio believe in many gods would be justified. But the truth is that Ibibio believe in the supremacy of Abasi Ibom over and above any other deity in many instances. For example, in a song usually sang during Nkim Itong festival (a festival of traditional medicine) in Uruan community where Mbia Ibok (traditional medicine men) used to test their power for superiority expresses it thus, enyene ibok adad adi Abasi miyakke mkpo inamke owo (whoever has juju let him bring as no harm would be inflicted on anyone except Abasi Ibom agrees). Again, an Ibibio proverb also expresses the fact thus otume mitoto Abasi ituaka isong meaning that the instrument used to harvest yam (otume) would not borrow the soil without first notifying God by way of acknowledging His sovereignty and supremacy. Usually, the harvest instrument would have to be raised upward first before borrowing the ground which for the Ibibio is an acknowledgment of God's supremacy during the harvesting of yam despite the believe-in a deity in-charge of farming and yields.

However, to understand Ibibio's position, one must take into consideration their cosmology which is premised on their metaphysics. The Ibibio like other Africans have a dualistic conception of the universe-physical and spiritual; in this case, the enyong (sky) and isong (earth). Both are abode of the Abasi Ibom (Supreme Being) and men, ancestors, localized deities, plants and animals respectively. The isong, though physical has a visible and an invisible dimension 
which is separated from each other by a metaphysical fence. The ancestors and localized deities occupy the invisible realm while man and the other terrestrial beings occupy the visible realm. Both realm though distinct in nature are integrative and complementary and combine to form a monistic harmonious universe. Higher and above all of them is the Abasi Ibom whose abode is beyond the physical universe.

Whether the deities actually exist or exist merely in the minds of the Africans are subject to debate. But whether the belief in them could substantially lead to invalidation or the denial of the Ibibio conception of and belief in the Supreme Being as non identical with the Supreme God of Christian religion is in fact non-sequitor. The Supreme Being (Abasi Ibom) exists and can exist independently of any belief in the minor or localized deity and Udo Etuk acknowledges and accepts this fact. The existence and nature of Abasi Ibom does not depend on the existence and non-existence of the minor deities. The beingness (ontology) of Abasi Ibom is and can be conceived in Ibibio ontology distinct from the existence of the localized deities or any consideration of any perceived or conceived relationship between the two. Since ontology cannot be subsumed in existentiality as the Existentialist tried to do with disastrous consequence to metaphysics, then the people's attitude cannot negate the essence of a being whose beingness does not depend on their attitude. The beingness of Abasi Ibom which guarantees His existence belongs to the noumenonal sphere (to use Kantian terminology) and the attitude of the people is in the phenomenal sphere. And the transition from phenomenal contemplation to noumenal conclusion would invariably ends as Kant observed in contradictions, antimonies, or paradoxes and so on; since a contrary position would be equally valid. Arguably again is the fact that there were many occasions that the children of Israel committed apostasy but these did not vitiate the essence of Yahweh. Their apostasy must have been a matter of ignorance or lack of proper understanding at that historical point. This goes to support the fact that epistemological proclivity depends on the ontology and not vice versa.

Udo Etuk's submission then of denying Abasi Ibom as identical with Jehovah God based on the Ibibio's belief in minor deities and their perceived relationship with the Supreme Being whom Yahweh repudiates seems a logical jump from existential plane (naïve metaphysics) to ontological conclusion. The two, the Supreme Being and the localized deities are of distinct nature in Ibibio reckoning. If at all, dependency should be an issue of consideration, then it should be the other way round; it is the existence of the localized deities that should be dependent on the validity of the belief in the Supreme Being. Since, the Supreme Being of the Christian religion repudiates the existence of minor deities then; denial of the existence of the localized deities would have been the logical conclusion from Udo Etuk's submission and not the denial of Abasi Ibom as identical with the God of Christianity. It appears, Udo Etuk is going from a posteriori argument to establish a priori conclusion. 
In a way, the Ibibio theocracy in intent and purpose, without prejudice to the Western conception, could be seen as Ibibio way of grappling and solving the problem of the lacuna created by the transcendentality of God in Western conception which resulted in Deus abscunditus in some scholars' interpretation. The localized deities then provide the needed linkage, social and contextual relevance. Again, this conception apparently dealt with the problem of evil as phenomena regarded as evil are attributable to these localized deities, so the Supreme Being is absolved from being linked with the problem of evil.

On the other hand, Udo Etuk's observation regarding African attachments to traditionalism is true. R.D. Jegede, A.O. Odejide and A.O. Sijuwola (1983) made the same submission thus:

Nigerians, like their African counterparts irrespective of their education, generally adhere in varying degrees to traditional African beliefs, such as those pertaining to causality. Events, especially unfavourable ones, do not just happen by chance, but are caused by supernatural forces. Thus, a man's sickness or his involvement in an accident may be attributed to the influence of another person who for some reasons harbors ill will towards the unfortunate victim.

But this could be ascribed to varied reasons principal of which could be due to their ontological and epistemological proclivities with over bearing emphasis on the supernatural in a complementary approach and not in a bifurcated way of Cartesian ontology. Another is the imposition of foreign stereotypes without proper catechesis and pains taking inculturation which has resulted in the alien nature of Christian tenets in spite of years of accepting the Christian faith.

However, by rejecting Ibibio Abasi Ibom based on this Ibibio attitude, Udo Etuk's (2002) seems to be recasting Bruhl's mind as represented by Printchard (1987) in the extract below thus:

We in Europe have behind us many centuries or rigorous intellectual speculation and analyses. Consequently, we are logically oriented in the sense that we normally seek the cause of phenomena in natural processes; and even when we face a phenomenon, which we cannot account for scientifically, we take it for granted that this is only because our knowledge is insufficient. Primitive thought has an altogether different character. It is oriented towards the supernatural.

Deductively, the African understanding or configuration of the Supreme Being and His relationship to other existents would be regarded as faulty simply because it does not follow the construct of Western rationality. From the above submission, it appears that the Ibibio (Africans) would have to be a ratiocentric in their conception of God to be regarded as identical with the Jewish God. But were the Jews ratiocentic in their conception of Yahweh? If I may ask, who determines the paradigm for rationality? Before now, Aristotelian symbolic logic was the only valid mode of reasoning. With time, the two valued logic have been 
complemented with three and many value logic which have been argued validly as veritable modes of reasoning. Since, there is a close corollary between philosophy and cultural proclivities then, the African understanding should be understood within the context of their reasoning. African (Ibibio) conception is premised on an ontology that is complementary, integrative and harmonious, therefore more humanistic and more relevant. Ibibio cosmology recognizes a dualistic universe (spiritual and physical) which are integrative and complementary. The spiritual world is the abode of the Supreme Being while the physical world is that of the gods, men and ancestors. In fact, the physical world as described above is of two dimensions, the physical (visible) and spiritual (invisible). Both are integrative since the spiritual dimension is not situated neither in the sky or beneath the earth, but side by side with the abode of living men, from whom the dead and the gods are separated by a fence, impassable to ordinary mortal (Talbot, 1962). Patrick Okure (1983) conceives this fence to be metaphysical meant to express the invisibility of the spirit world.

Apparently, Udo Etuk as a Christian cleric is writing primarily in defense of the Christian faith as handed over and understood by the Missionaries and not necessarily concerned with understanding the Africans in their own right. He, like Placide Temples (1959) is "talking of" the Ibibio without necessarily "talking for" or "talking to" the Ibibio based on his familiar Western typologies and understanding. It would be difficult to expect him to go beyond these typologies to appreciate the Ibibio challenges in grappling with issue of God within its ontology. Without any intention of committing ad hominem fallacy, this paper is persuaded from Udo Etuk's submission to see his worry as a betrayal of prejudice which is understandable given his background and his very reason of writing which is in defense of the Christian faith as brought by the Western Missionaries.

\section{Conclusion}

It should however be noted that the issue of the existence of minor deities in African traditional religion is as expected a progression of natural religions. The intermediacy of nature and minor deities is supposed to make up for the missing link created by the transcendentality of the Supreme Being. Even the revealed religions have such intermediaries in saints in heaven, devout men and women on earth and angels. Maybe the understanding of the Ibibio could be seen as historical configuration based on historical situation. But like the Athenians who had the altar for the unknown God (Acts 17: 23-31) whose essence was not vitiated by their belief in other deities, so the Ibibio Abasi Ibom is in essence identical with that of the Jews irrespective of Ibibio believe in minor deities whose conception and mode of operation is different from that acceptable in Christianity. It is left for Christian's theologians and apologists to inculturate the good ideas in Ibibio thought while discarding the offensive. Denying the Ibibio Abasi Ibom the profundity of the omnipotent God based on the supposed fault in Ibibio at- 
titude and belief in minor deities is like throwing away the baby with the dirty water.

The logical conclusion, I envisaged would be, on the one hand, the classification of all Ibibio nay all Africans Christians as superstitious and atheist and on the other hand, the fatal consequence of total rejection of Christianity by the Ibibio. Ironically, there is no culture, in truth that is a Christian culture not even the Jewish or Western culture but every culture is capable of being Christianized. This must have informed the Council Fathers in Evangelii Nuntiani (Paul VI, 1975: No. 53) to admonish that "the evangelizer should exhibit respect to even non-Christian religion since they are living expressions of the soul of vast human groups and echoes thousands of years of their search for God. They often possess an impressive heritage of profoundly religious texts sprinkled with countless seeds of the word, therefore an authentic preparation for the gospel". Though, the Council Fathers also advised for the exercise of discernment so as not to compromise the essential tenets of faith which could result in confusion, syncretism and false particularization.

Informed by this position, the Second Vatican Council in Nostrae Aetate (Flannery, 1990: Art 3) submits:

Upon the Muslims too, the church looks with esteem. They adore God, living and enduring, merciful and earth... Though, they do not acknowledge Jesus as God they revere Him as a prophet. They also honour Mary, his virgin-Mother; at times call on her too with devotion.

Commenting on these remarks, Felix M. Pareja (1969) observes that the Council takes only the Muslims theodicy into consideration and not their faith which include the prophetic mission of Mohammed. Despite some shortcomings in their conception of the divinity of Jesus and Jesus resurrection which are the pivots of Christian dogma, faith and a condition for going to Heaven, the Document in Eccelsiam Suam (Paul VI, 1964: Art 40) admits that "the solemn recognition of Allah as the one true God and creator may be regarded as a foundation for dialoguing with the Muslims.

Dialoguing with the Ibibio on the issue of religion would be meaningful if it is not polarized with condemnation rather by appreciating the positive aspects of Ibibio religion which invariably would include their belief in Abasi Ibom as one supreme, transcendent, subsisting, and sovereign God.

\section{Conflicts of Interest}

The author declares no conflicts of interest regarding the publication of this paper.

\section{References}

Achebe, C. (1958). Things Fall Apart. London: Heinemann

Esen, A. J. (1982). Ibibio Profile. Calabar: Pacific Press.

Etim, F. (2006). Issues in Philosophy of Religion. Uyo: Inela Ventures. 
Etim, F. (2013a). African Philosophy: The Story So Far. Uyo: COMM-WATCH Productions.

Etim, F. (2013b). Metaphysics of African Medicine. Uyo: Minder Press.

Etuk, U. (2000). The Riches of Philosophy. Uyo: Scholars Press.

Etuk, U. (2002). God of Africa. In Religion and Cultural Identity. Ibadan: Hope Publications.

Flannery, A. (Ed.) (1990). Nostae Aetate. Vatican Council II Document. New York: Costelo Publishing.

Idowu, B. E. (1973). African Traditional Religion: A Definition. London: SCM.

Jegede, R. O., Odejide, A. O., \& Sijuwola, A. O. (1983). Rural Mental Care in Nigeria. International Journal of Mental Health, 12, 159-169.

https://doi.org/10.1080/00207411.1983.11448943

Mbebeng, I. and Essien, E. (N.Y). Christianity in Efik and Ibibio Nations: So Far So Bad. (A Pamphlet). N.P: N.D.

Mbiti, J. S. (1970). Concepts of God in Africa. London: S.P.C.P.

Okure, P. (1983). The Concept of Justice among the Ibibio People. PhD Thesis.

Pareja, F. M. (1969). Islam. In K. Rahner (Ed.), Sacramentum Mundi (Art 3). New York: Harder and Herden.

Parrinder, G. (1976). Africa's Three Religions. London: Sheldon Press.

Paul VI (1964). Ecclesiam Suam (Encyclical on the Unity of the Church) August 6, 1964. Acta Apostolicae, 56, 609-659.

Paul VI (1975). Evangeli Nuntiani. Encyclical on Evangelization in the Modern World.

Printchard, E. E. (1987). Theories of Primitive Religion. New York: Oxford University Press.

Talbot, D. A. (1962). Life in Southern Nigeria. London: Frank Cass.

Temples, P. (1959). Bantu Philosophy. Paris: Presence Africaine.

The Holy Bible (1971). The Holy Bible (Revised Standard Version). New York: Collins Clear-Type Press.

Udo, E. A. (1983). Who Are the Ibibio? Onitsha: Africana-FEB Publishers. 